\title{
Murnau's Nosferatu
}

\author{
By Julio Ángel Olivares Merino
}

Fall 2001 Issue of KINEMA

\section{MURNAU'S NOSFERATU: TAMING FLAMES, PITCH BLACK, SLEEPWALKING SER- PENTS AND THE WORDS OF ICE THAT CAME FROM WITHIN}

\section{Ambiguous "Givens" and Texture: The Trace Within}

Ageless, summoned and raised each nightfall by the beating thirst echoing the eternal search for blood, Count Dracula, the old tyrant, stands at the edge of insanity, at the threshold of his forgotten land, with vigilant eyes staring at the forest, expecting the coming of the messiah of forgiveness and joy. Beyond the veils of reason and the landscapes of logic, as a tradition and symbol of a time gone, of the forlorn black gem buried in the vaults of remembrance, he, the mannequin of shadows, murmurs the silence of trauma.

In Murnau's morality play, the vampire's lust for blood is simply a preying of the revulsed grotesque and repressed violence upon innocence and blissful modesty. The story deals, in essence, with the struggle for ideals, the tragic sequence of sacrifices and tortures of necessary purgation that ultimately results in a despairing lack of Aristotelian "cleansing" or catharsis of the self.

Awakening within his dreams of trembling shrouds, in Nosferatu (1922), Murnau masters the existentialist symphony of a horrifying and expressionist nightmare about escapism, homesickness, colonization, fear, depression, love and disdain - not long before Carl T. Dryer, in Vampyr (1931), would dare to provide us with another apocalyptic, surrealistic vision of existence and life within a dream, of the melancholy and damnation that clothe the world of chimeras from beyond the glassy soul of a casket.

Murnau's discourse is based on the deconstruction and ulterior dethronement of the dream of colonization and thirst for absolute power. The menace of self-destruction that is latent in the embracing of the alienated, the pact with the outer limits of the age and social understanding, pose as threats to the status quo, the ballad-like marriage of reason and will, love and tradition, through the arrival of decay and apocalyptic chaos, embodied both in the vampire's undefined nature and its atemporal surroundings, the Transylvanian labyrinths of mists, beyond conventional knowledge and register.

Portrayed as a stable land enslaved to the beatings of time - the film opens with a brief high-angle shot of a clock tower beside the city - the Occidental world Bremen is an image of static modernity. In contrast to the city's aureole of resigned tranquility, dynamism in Murnau's universe strikes like the vertiginous beating of an innovating system of horror, imbalance and lasting agony.

Happily married, Jonathan Harker is an undefined spore, a grain in the collectivity inside the molds of Bremen's pedestrian status quo and hierarchy. His initial narcissistic smile before the mirror expresses the traditional blessings felt with no essence beyond the saturated joy of a state of immobility. Behind that apparent stillness, beyond that "domestic bliss" (Waller, 1986:179), a great deal of haunting temptations for self-esteem flows deep within the Occidental's mind:

$[T]$ he remainder of this opening sequence suggests how little Jonathan does or can see. In his boyish, buoyant desire to get to work, Jonathan is blind to his wife's pensiveness and her seemingly exaggerated grief at his departure, and also to his employer's exceedingly old appearance and suspicious behaviour - all details that the camera singles out for us in iris-masked close-ups. (Waller, 1986:179)

In fact, as we will gradually discover, identity and commodity for Harker are more than just a constructed image of the private familiar nucleus on the quotidian canvas of breeze, on the mirror, contextualized within the monotonous succession of seasons. Free will restlessly deconstructs his bourgeois character. Clad in innocence and ingenuity, Harker longs for maturity, even though that means leaving his world and wife behind, renouncing the habitual, conventional meanings that are firmly established in the minds of his society. The parting scene is not, this time, just a separation of woman and man as a clear reflection of sex roles (M. Lowe, 1982:70), the former "condescendingly" obliged to wait until her husband's return; it 
is not a common leaving of the private space heading for the work setting but a rebellion against domestic conformity. Consequently, it is not only that man has the right to work but also to dream.

A bouquet of flowers cut from their "modern Garden of Eden" (Waller, 1986:179) is the last tinge of beauty Harker decides to take and give. Those petals he initially hides in jealousy from his wife's view, probably symbolize the forbidden touch of disgrace and prelude the loss of Paradise. Those flowers, away from Nina's eyes that still charm him - together with the postcard-like embrace that chains him to the dead calm of his tedious life, are Harker's last homages to his previous existence and state, to his family. His smile is a stigma of obsessive fascination at the prospect of a new day, the first of revolution. From that moment on, he will just take and not give; he will just get, have or sell, as the unique merchant of his fate - or so he thinks.

Nosferatu begins with a departure, a dynamic and traumatic shift. Harker's physical movement towards the land beyond the forest and his psychological alienation, a turning point from the static and pleasurable beginning, brings forth the abyss and stigmata of horror. Undoubtedly, the stimulus for this sudden trip to Transylvania is to be found, on the one hand, in the initial materialistic temptation made by Harker's menacing employer Renfield as the travel offers "a good opportunity" to earn money and improve within the social hierarchy. On the other hand, it also has a basis in the Occidental's inner longing for truth and reason, an Eve-like thirst for knowledge that makes him rebel against his Oedipus complex and adopt a Narcissistic character, "analogous to maternal mirroring, essential to identity development, object relatedness, and selfesteem." (Berman, 1991:6).

The undiscovered, gloomy, and hostile land on the map Renfield points to in the darkness of his study excites Harker's fertile mind at the prospect of the trip, one that will cost him "pain and even a little blood. Renfield, histrionic and phantasmagoric - with a hint of insanity in his freakish laughter - definitely resembles Mephistopheles; his offer also echoes Lucifer's bargaining for Faust's soul. In fact, Harker's departure - very much in the sense of A. G. Greimas' alienation tales - implies following a path of initiation, a longing for a new awakening, a new beginning and the necessity for a new father, a way of desiring which is, in essence, a coming back to the original primitive state, a regression. ${ }^{(1)}$

Murnau's discourse matches those tales that, from a Freudian perspective, constitute the current of "familiar novels of neurosis," narratives that deal with the subversion of the subject from the enslavement of parents' custody, resulting in the battle between the ego, the superego and the non-repressed manifestation of the self, the alter ego. Following Marthe Robert's vision of lost innocence, we have to assume Harker is like that grown child who, transcending the Eden of ideal parental love and caress, disappointingly realizes the limits outside the bosom are inhabited by all those beings - the others - who have the potential ability to play the role of father and mother, being even superior to his or her own progenitors. The sufferer's unique response to this traumatic spasm of unexpected revelations is the conscious and obsessive search for another world and system, an alternative universe or reality in which his or her desires may become true, a longing search that is nothing but dreaming.

By travelling to Transylvania Harker - the ego - already an orphan (as no allusion to his parents is made) renounces his own domesticity and familiar circumstances, leaving his wife - instead of father - behind, not killing her but replacing his married state with a productive involution, the magic of birth revisited, which takes him back to the adventure of childhood, the discovery of free will and suspense, and vivid fear, the risky tests of initiation in fairy tales which are necessary to achieve a life and fundamental existence of grace (Bettelheim, 1979).

Menacingly surrounded by those alienated and oppressive elements which were familiar once, the system he represents being distorted now in a set of rules he silently opposes, Harker feels the marginal isolation of the antagonist - like a subversive and antisocial exception within the pattern - a psychological scar from sin very much like Mina's mark of shame upon her forehead (Stoker, 1993:3 81-82) or Shelley's unearthed monstrous creature's self reproach: "I had admired the perfect forms of my cottagers - their grace, beauty, and delicate complexions: but how I was terrified, when I viewed myself in a transparent pool. At first I started back, unable to believe that it was indeed I who was reflected in the mirror [...] I became fully convinced that I was in reality the monster that I am"- the stranger in a strange land, and prefers to flee away rather than to remain functioning as a threat to all the conventions. (Shelley, 1980:100) 
Harker attempts to deconstruct his present by first negating himself - the masquerade he is living at Bremen - and then, employing his imagination in a process of bizarre self-discovery.

The fixed present of pleasures and system of solid boundaries and conventions Harker flees from is a text that presumably exists but which does not and will not express a valid essence until he, the Cainian slave to forbidden knowledge, becomes the recipient of its texture and interprets it, like the words and marks on pages that are meaningless, just "givens" of a "disappearing text" (Fish, 1981). Harker's bourgeois Bremen, his present, needs the active involvement of his consciousness, the "activation of a subject-object relationship" (Eco, 1979:118) to be concretized. As Iser points out, "a text can only come to life when it is read" $(1971: 2-3){ }^{(2)}$

The process of interpretation and means of experiencing the text to endow it with life and determinate meaning, implies an intercourse with idealism and allegories of the otherness. In other words, it involves a process of alienation (Entfremdung, in Hegel's term). Harker leaves the unadventurous common sense, the here-and-now - indispensable to sanity - because he feels his stability is just the sum of encoded meanings that are not his own and which were already in the language he acquired as a child, suddenly realizing he is "exposed to meanings that serve the interest of an older authoritarian group" (Fowler, 1986:30). ${ }^{(3)}$ His ideological shift of mode demonstrates that pluralism, and not determinism, rules. An anonymous and resigned actant, a shadow from the old order, however, tries to prevent Harker from leaving the spot, warning him not to see beyond, to accept the primitive text:

Wait young man. You can't escape destiny by running away...

The Caligari-like real Estate Agent Renfield, stylised with exaggerated physical mannerisms, maniacal laughter and flaming dead hair, reveals the indeterminacies of Harker's present - both being clad in dark colours. By the presentation of Dracula's letter, a text written in cryptic hieroglyphs, he brings out part of the exotic and persuasive mystic calling from beyond - in "some lost corner of the Carpathians," tempting him to search beyond the limits of urban life so as to restore his origin.

Harker chooses the utopia of potential change and, metaphorically dying to the world, he hurries on "from relay, throughout the dust raised by the stages." Dust or ashes. Ashes to ashes, dust to dust since Nina mourns his departure, wearing the black of horrible omens.

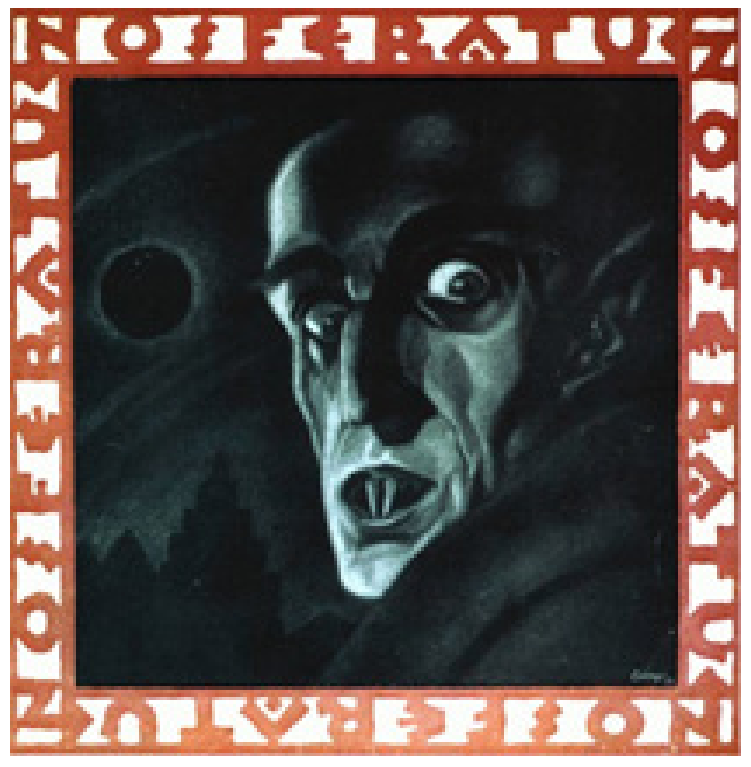

Figure 1: Nosferatu (F. W. Murnau 1922)

\section{Textualities of Distortion: through the Rhymes of Regression}

The pilgrim reaches the Land Of Phantoms and Castle Dracula after leaving Bremen on horseback, passing through a massive natural vastness. Its strange symmetrical beauty of valleys and forests are in discord 
with expressionist principles, best exemplified by the terrifying backgrounds and settings surrounding the actors in Robert Wiene's The Cabinet of Dr. Caligari (1919) and in contrast to Harker's enclosed garden. The voyager trespasses the frontier of the "familiar territory" (Iser, 1978, 87), a landmark where text and reader meet to initiate communication. The latter abandons himself to the trance, crossing the bridge on foot and falling into the abyss of conscious dream, an image-making chimera and transcendentalism within the agent's mind, "the wandering viewpoint" (Fish, 1981:7).

The aesthetic pleasure Harker is avid for consists of two moments. The first state is that of "unmediated surrender ( ... ) also applicable to all pleasure" (Jauss, 1982:30-31) of the ego to the object. This is the Occidental's initial situation, his consideration of his domestic tranquility, his looking into the mirror, the moment in which he sees over the shroud of his present and falls to the temptation of a renewal. The second moment, "peculiar to aesthetic pleasure" (Jauss, 1982:30-31) is the instant of recreation, an act of consciousness and self-discovery that derives from an imaginative materialization of dreams. In Harker's case, it is the praxis of the weird conceived, followed by a process of familiarization with the alien landscape and surroundings - and finally his homodiegetic associative identification, his active participation in the text of laments.

Once Harker crosses the gates of retrospection, he is born for a second time, like Rousseau's Prototype of the innocent thrown into the wilderness, the abyssal castle in this case. Consequently, the travelogue stands for a progressive pre-birth interval involving several acts, from the mundane, from comfort and confidence, to the dark isolation of the horror finally revealed. To be more explicit:

- Alienation. Harker leaves his habitat and transcends the borders of his everyday life.

- Arrival at the inn. Well-meant warnings issue from human - the superstitious peasants ${ }^{(4)}$ and nonhuman sources - The Book of Vampires.

- Surrounded by the decrepit claws of nightfall, the murmuring prayers of the natives, the restless image of horses going away threatened by the hyena, an anticipative rhyme unveiling the horror of the vampiric predator lurking beyond the mists in the Carpathians, Harker falls asleep within the embryo of the exhiling text and gets deeper into the dream, awaking on a sunny and calm day.

- Transgression. When the new born Harker disregards the warnings and crosses the bridge, everything collapses into the impossible, the image now being in negative. The coach will rapidly take Harker to the castle or womb for the imminent rebirth. The last human beings he sees, apart from the coachman, are those he has left behind at the inn, even though a flux of contacts with the primitive text will remain - that of his letters to Nina ${ }^{(5)}$ and his reception of her warning from beyond.

- Dark Father's or false hero's welcome, Pre-punishment. On arrival at the castle, the camera leaves part of Harker's silhouette out of the frame, his identity being gradually diffused. When the Westerner and the Lord of Shadows meet, both figures are in chiaroscuro and seen in silhouette. Harker takes off his hat showing admiration and respect before the authoritative figure of the vampire, who even scolds him fatherly "You are late, young man. It is almost midnight." Drawn into the orbit of the enemy, the effeminate Harker is metaphorically reborn within the walls of Castle Dracula and is eventually victimized by the undead. ${ }^{(6)}$

The next morning, the genesis of the new reality. Like a disorientated child with limited consciousness, Harker goes through the doors of the bare and unkept castle, having access to its decaying monotony. ${ }^{(7)}$

Like Frankenstein's grotesque creation and Milton's Eve, the initiated Harker feels bewildered after his awakening. There is no mirror in the abyss to tell him about his new state but this smile of sufficiency and well-being at the beginning of the film is still maintained. ${ }^{(8)}$ However, desperation increases as Harker's narcissistic desire to reflect on pools of meditation and recognition fails to be materialized, implying a gradual process of decadence towards invisibility, absence and death. In his letter to Nina, he leaves the last traces of his old self on the reality he has abandoned.

In Transylvania, Harker discovers the ambiguity of the new patriarchal figure, Dracula, and is overwhelmed by his weird and pest-like essence of malady, tortured by the vampire's remains of glory and his faded eyes, witnesses of extinct battle flames. Terror and horror, as indulgent forms of self-disgust, are born within Harker's contemplative conscience as the deprivation of the self materializes. 
Murnau's undead does not nurture the child but instead, psychologically and physically rapes his victim. Not only does Dracula explicitly feed on Harker's blood but, even more so on his trace, his past, present and future, all amalgamated in Nina's portrait - that the undead mentally steals in an analogy to Victor Frankenstein's deprivation of his mother's picture. ${ }^{(9)}$

Dracula's glorious memories, more agonizing in Herzog's revisited version Nosferatu, the Vampyre (1979), in which the revenant "has a pathos and tragic dignity absent from Max Schreck's performance" (Prawer, 1980:72), ${ }^{(10)}$ resemble the awakening of Shelley's hopeless creature's sense of self-repulsion and need for a companion to compensate "his" suffering. Furthermore, the arrival of the one who considers the vampire as a father, that "son" who offers him a home for his return to the West, reminds the undead of his hypothetical beloved, the mother, both Nina and Bremen now, the city and paradise he has dreamt of for decades in the shadows.

In fact, from the moment Dracula, the snatcher, discovers Nina's beauty, the vampire is also prompted to transcend the veils of his horizon "a standpoint that limits the possibility of vision" (Gadainer, 1972:289) by stealing Harker from his soul and taking possession of his background, - so that Nina, the icon of purity, may redeem his hermetic existence of the macabre and decay.

It is clear then that the vampire aspires to project an image of himself into the civilized future and eternally abide in the rolling of times in the same way Harker longs to find a mould and cradle for his rebirth, both being ways of surviving a moment of crisis and subversion in their life or unlife.

Harker, the other part in the monstrous fraternity - like Victor Frankenstein and his ghastly creation- soon realizes, with terrifying disgust and frustration, that the subordinated text of his life - that creative drive towards knowledge and discovery - has suddenly become distorted. He is unable to sort out or impose structure on the nightmare he is living and is in perplexity and fear, since the vampire is about to leave his reign of tearing winds and desolation for him to inherit Harker must directly engage and manage this subjective reality without a frame of reference in the world of common sense or natural phenomena.

However, we discover Harker is not alone in his alternative dream of deconstruction. Not only is he shadowed by his prospective victimizer, Dracula, but also by his redeemer in the distance, Nina. It is not by chance that Harker's languid wife invokes the texture of unreality from the silent seashore, by the ruined and protruding graveyard of Bremen. Not by chance either are her sleepwalking trances presented by inter-cutting shots with the Transylvanian images showing Harker's victimization, those states that show her desire to warn her beloved lost in the text of isolation. ${ }^{(11)}$ It is a trance she will never escape from until her death in the peace of catharsis once the world's balance is restored.

Nosferatu's fatal patriarchal role reaches its darkest and most poignant reading in two scenes that precede the undead's departure to Bremen. The first is when the vampire implicitly drinks blood from the terrified Harker, who cowers under the bedcovers, a much more intense and shocking feeding portrait than the absolute ellipsis of the first biting approach during the first night, later suggested by the two punctures on the Occidental's neck. The second occurs when, eventually discovering the undead, Harker loses his balance and crawls away after having a clear and obviously threatening sight of the vampire's fangs. ${ }^{(12)}$

Harker's terror could well be the manifestation of an inner fight provoked by the anarchic desire to transcend social boundaries. ${ }^{(13)}$ His repentance, the struggle to preserve his innocence against the alternative dreams he has sought, and the desire to regain his daily life, comes precisely when it seems too late for him, when he begins racing back to the Occident for the antagonist as the "Demeter" cuts through the open sea, "driven by the fatal breath of the vampire". At the same time, the undead is gradually turning now from an individual to a collective supreme evil nightmare and foe, ${ }^{(14)}$ the shade of regression in modern enlightenment, "a constant reminder of the many Old World traditions that never quite made the transition to contemporary society" (Waller, 1986:4).

In fact, while together in the castle, both Harker and Nosferatu, in the desire for self-improvement, build a paradigm of dreams - choices away from the norm - alternative constituents of the form and meaning of their current text - one, the bourgeois state; the other, the realm of darkness - and in doing so they exchange roles. Harker's western light searches for darkness whereas the uncivilized East looks for the dream of love, which is another mode of the eternal thirst for the imperishable flesh in sin and justifies his wandering victimization. 
As Frankenstein's monster says: "I am malicious because I am miserable" (Shelley, 1980:145). Damnation is released once they part from each other, when they attempt to live independently with the carcass of the other. Essence soon fades, Harker drowning in the solitude of cloistered silence and the vampire heading for modernity, the collective arena, where Nina's suffering hope - finally materialized in the first lethal ray of dawn - will kill him.

The obvious result of this mutual and analogous displacement is an ill and painful lack of texture - absence of cohesion and coherence and the absolute ruin of the dreamed escape and improvement - Harker, on the one hand, facilitating the invasion of icons of horror into the city and the community, and, on the other, Nosferatu accepting the death of his nightfall kingdom.

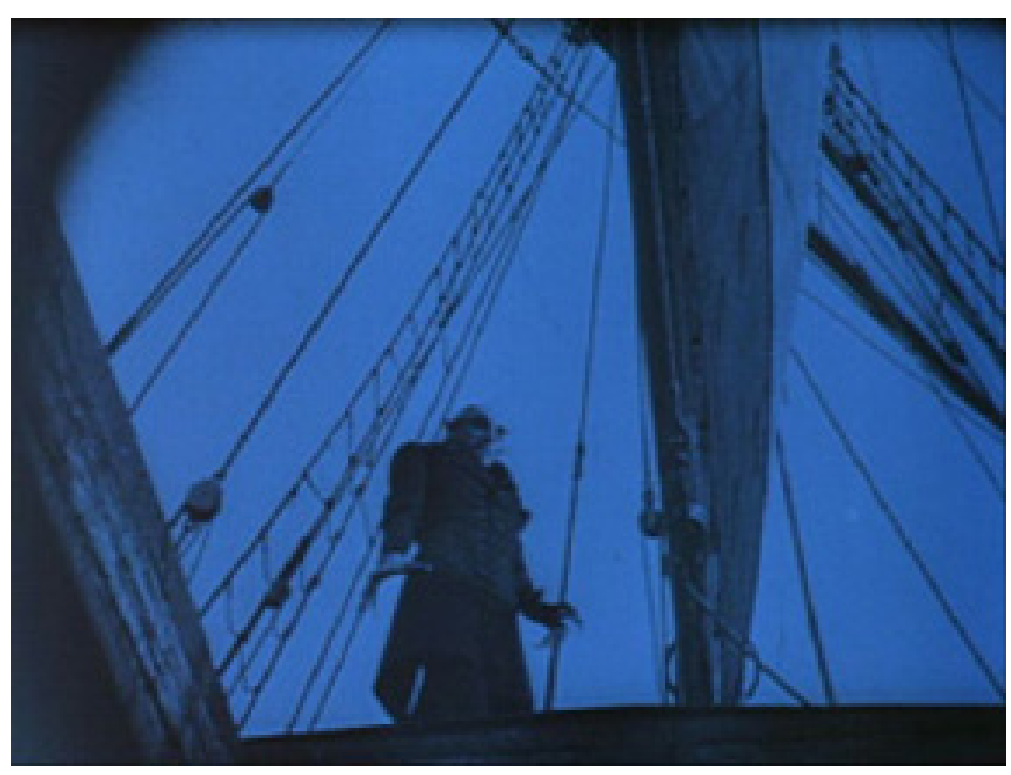

Figure 2: Nosferatu (F. W. Murnau 1922)

\section{Silence: Text of Immolation and Purge}

After Dracula, now the imago, leaves Harker - now the umbra - in the fortress of the past, the vampire pursues his path towards civilization. However, damnation is waiting. Harker awakes from lethargy by the side of two religious benefactors and immediately goes in pursuit of the victimizer. This dynamism results in the two alienated lives reentering the primitive text of the present the undead fulfilling his voyeuristic desires to plague the labyrinths of civilization and Harker wandering the streets he had once left.

Reverting from his infant state and recovering an adolescent passion for Nina, both Harker and the vampire now head for the same source of salvation, each of them pretending to come back home to Nina's bosom so as to show the other is the real stranger to be despised and destroyed.

In fact, Nina is also alienated, both domestically and psychologically. Once her beloved departs, she is destined to stay with her friends, Westenra and his wife, surely having inner traumas when exposed to a love relationship that is not her own. She is also involved in the other major alienation in the film, the decay of Bremen, the city that becomes a macro-sepulchre, "the nineteenth-century antecedents of the besieged, easily invaded, crumbling America that has become a primary subject of the contemporary horror story" (Waller, 1986:226).

Bremen, the undead's destiny, is unprotected, defenceless and vulnerable against this plague carrier's arrival. $^{(15)}$ It is no longer the luminous and familiar one-street town Jonathan left when heading for Dracula's land but a city of closed doors and windows, homes in which young and old people prefer to die "as a unit in private" (Waller, 1986:189).

In contrast to Stoker's novel, the ghost ship does not wreck but glides through the monochromatic vacant soul of this dormant town whose death is reflected on the still and docile water. The city is undressed of 
joy and life by Murnau's impersonal long shots of desolate streets in which the vampire will wander freely, a town whose port now welcomes the plague and a dark age.

The dwelling in which the undead settles is that niche-walled, six-story building among silent and desolate factories ${ }^{(16)}$ that had anticipated decay at the very beginning of the film and which now flourishes with splendour in the context of pestilence. It faces both Harker's home - "We shall be neighbours," Nosferatu promises Harker on signing the pact - and Renfield's enclave. Having no home during the trance of alienation - just like Harker in Transylvania - Nosferatu carries his coffins as shelters on the road before finding himself comfortable in Carfax as a bourgeois of the bizarre.

Damned, like Lilith and Satan, to wander in darkness in perpetual thirst, Nosferatu's hunger for blood soon changes into a search for identity, a caprice for love, and the renewal of his spirit. The only way to transcend his frustration of centuries is to colonize the system, usurp the order of modernity and enthrone himself as the supreme anachronism after the plague has devastated Bremen and Nina is finally his own. In fact, the undead will have no opposition from Harker, who is but a static character, whose life is still to be restored. At the suspense-filled end of the film, Nosferatu and Nina - in an approaching movement of attraction and repulsion - become the semantic nuclei of the distorted text their actions defining the film's resolution. ${ }^{(17)}$

If Frankenstein's unloved monster had vowed vengeance, "mine shall not be submission of abject slavery. I will revenge my injuries; if I cannot inspire love, I will cause fear." (Shelley, 1980:145) - Dracula's discourse is a weak and beaten one. In the end, courtesy and renunciation become the causes of his self-destruction. Eager to experience his loving side, he approaches Nina in the form of a threatening elongated shadow representing a mixture of both the absent Harker and the horrendous vampire - and sleeps beside her in the darkness. In a superficially passive attitude of condescendence, "Nina is not willingly seduced, she is violated, raped. Her corpse-like passivity as the vampire feeds on her signifies acquiescence, not pleasure" Waller, 1986:193). She, pure in heart, employing the covert strategy of sentiment after sewing the words "Ich liebe Dich" as a motif for her enterprise, tempts him to feel her neck.

No Cocteau's romance between beast and beauty is inferred here, however. Instead, reflected is the social awakening of the "new woman," the Cleopatra of the Twentieth Century, "the Wagnerian (Flying Dutchman) motif of the woman who lays down her life to bring salvation to the man she loves and, through him, to mankind" (Prawer, 1980:49). Nina is the saviour who lures the vampire to her bed and detains him to his death - after he has dried her heart by literally squeezing it. With the beams of the rising sun, the vassal Renfield confirms - "The Master is Dead", thus the world is restored to its primitive text, purged of the uncanny.

This is all achieved as Nina, like a flickering candle facing the window, simultaneously dies - crying the name of her beloved in her act of self-sacrifice. Death embraced, Harker the emotionally self-indulgent adolescent loses his innocence and unambiguously reenters the system. The narrator's formulaic epilogue - summarizing a regenerated sense of harmony - reads:

And at that moment, as if by a miracle, the sick no longer died, and the stifling shadow of the vampire vanished with the morning sun.

Happy end, then? The emphatic references to the revolutionary abyss and the seeds of the alternative still remain undimmed in our mind when the film fades in the melancholic drooping notes of the piano. The persistence of the vampiric threat is not the restless sediment of disgrace that stays after the sad closure; it is, instead and unfortunately, the assurance that it is always the innocent who suffer and die to settle the pillars of the future. When the final curtains fall, we wonder where the processions of coffins, the girl with the ball and all those unnamed victims in the mob have gone. In the end, glory tiptoes past the heroine's fate, granting her no reward, no regeneration in the status of normality recovered, but just the audience's sympathy. Nina becomes the lost meaning, a dead metaphor that loses prominence. Her illusions wither, her blood and life finally kept in the invisible bosom of the disappeared vampire's veins. Was her beloved Harker and Bremen really worth her death? Dead Nina, mother of the future text's inhabitants and means of transmission of the traditional code, shares for the first and last time the nuptial bed with Jonathan. No pleasure but pain. The antagonist disappears; the heroine remains to be praised and wept by the unworthy husband. 
Harker's silent tears do not compensate her weeping cries, eternally heard; neither does his hypothetical remorse.

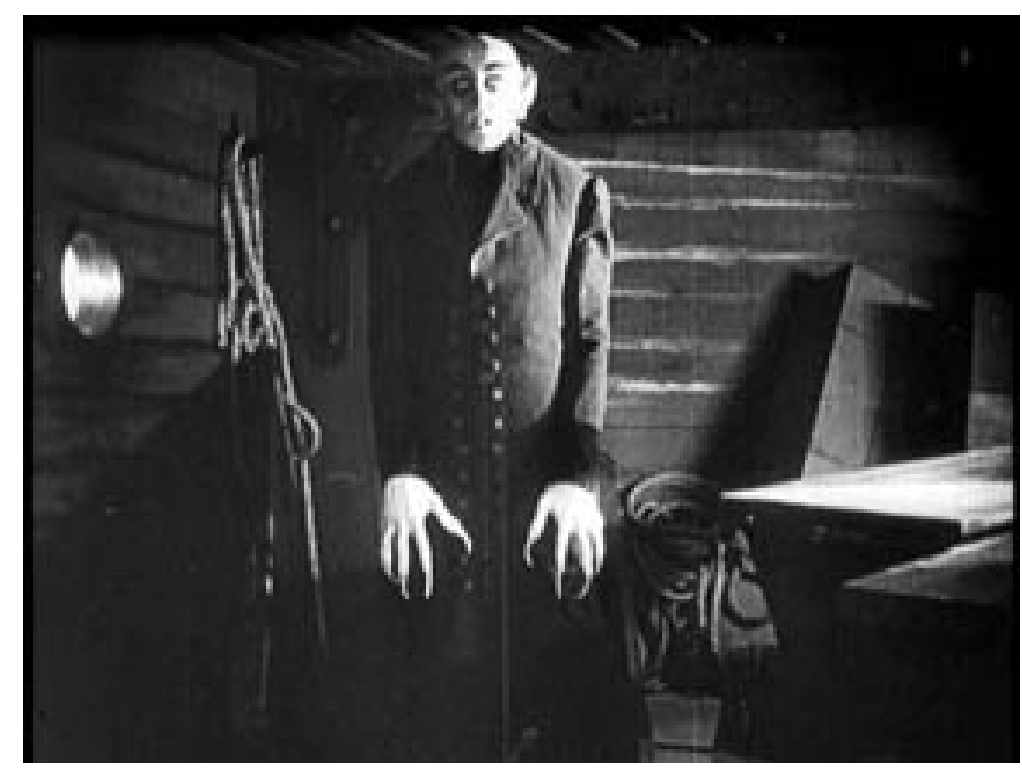

Figure 3: Max Schreck in Nosferatu

\section{Notes}

1. Harker's movement into the land of mists is like an allegorical excursion into the terrors of the attic or the cellar, the dark dimensions where forbidden secrets are gathered or where the worst nightmares take place. 2 . Very much like Stoker's Dracula, Murnau's Nosferatu is an assembly of different texts, split up into different narrative levels: the research conclusions of historian and omniscient narrator Johan Cavallius; Harker's letters to Nina; the strange hieroglyphs on Dracula's letter; the same "rotten" language in the contract that grants the vampire access to the core of civilization; the newspaper announcing the Master's arrival to Renfield; the Demeter's log as an intermediate nightmare at the sea; and, obviously, in the editing of the film as a whole, the titles with their supporting verbal accounts of the visual construct, as well as the shifts in the narrative pace, ellipsis, descriptive pauses and presentation of actual words and indirect presentation of characters interacting. Also the imprinted discourse, the "pseudoscientific and folkloric explanation of the repressed" in The Book of Vampires. 3. These odysseys mainly result in an intensification of suffering and imbalance. In essence, however, they also grant fulfilment since they assure completion of the personality as expressed in the following quotation: It is this end which is the goal of the adventure of self-meeting. If we ask why it should be sought, when the seeking is so often unpleasant and even fatal, we can only answer that there appears to be in living creatures generally the urge to do a thing which can never be justified in practical terms: to see the unseen, to sail beyond the sunset, to cross the mountains of the moon. And when the uncrossed mountains are within as well as without (...) when this is the case there seems to be a special urgency, arising out of a sense of incompleteness, even of self-deception and self-deprivation. For to live as only half oneself is to live a kind of lie, and to live a kind of lie is to live a kind of death. (Keppler, 1972:201) 4. We could consider these actants, the peasants clad in folkloric costumes, as ancestors in a feudal system, an obsolete mode of rural living based on the primacy of fear, superstition and oppression. Consequently, both the inn and the castle are spatial antithesis to Harker's home and his industrial Bremen, part of the construct of the hallucination, of the text created, although being as real as the Occidental's dwelling and his city of origin. (Waller, 1986:181). 5. The letter seems to be closing a door to the past, Harker being avid to gain independence from the protection and sheltering figure of his wife In it, Harker acts as a psychic vampire, assuring his absence, temporal or perennial, will not disturb the order in the primitive text. "Free me", he seems to be saying "I am independent and worth my life, my dream. I will walk alone from this 
moment on". There is no summons for a future contact. Furthermore, these lines also serve as an act of self discovery, a way of testing himself. The letter shows Harker's obsession to fill the incomplete, to reflect on what has just happened during the past night, on everything that awaits him. Nina is just the perfect addressee to whom he feels he must externalize and objectivize his thoughts about the alternative reality he has recently entered. 6. No female vampire tempts Harker in Castle Dracula, no three voluptuous lamia attempt to rape him and drink his blood, as happens in Stoker's original work. If in Stoker's masterpiece, the woman has a menacing role representing the dark mother, in Murnau, the prologue of the story includes no other femininity apart from Nina and the flat female witch-like women in the inn at the Balkans. The role of masculinity in Nosferatu, symbolised by Harker's, Renfield's and the vampire's selfishness, gradually degenerates and decays from smile to desperation. In the case of the vampire, we find an accentuation of his inner illness and weakness - as female values grow in the second part of the film. Masculinity has no sense, no prominence, just being a doomed race, dying in the embrace of the plague or remaining in a frozen pose after the cataclysm is gone. 7. As Waller reflects: "In Nosferatu, opening a door or window is an action as dangerous as it is necessary; it is an action that creates the possibility for both exit and entrance,. for seeing and being seen, for letting in the sunlight and letting in infection and darkness." (Waller, 1986:182) 8. Harker's smile, materializing in shrieks of laughter at times of edgy excitation is a constant, one of those "givens" from the quotidian text of the present, that will turn into a pale mask of horror when confronted with the silhouette of the menacing vampire. According to Waller: "Jonathan's laughter seems to be a matter of smug condescension and stupidity rather than an outright attempt at ridicule, for he has laughed at Nina in much the same way. Whether or not Murnau desired Gustav Von Wagenheim to portray Jonathan in the manner he does, the effect of Von Wagenheim's performance is to render the young traveller a shortsighted, foolish egotist." (19:180-181) 9. Harker kisses Nina's portrait, but only because the vampire seems to take notice of it when the Occidental is obsessively concentrated on the contract. The kiss is an act of egotism and probably fetishism as Harker just feels the attraction for the frozen image. The portrait is soon put back into the bag where forgotten and despised things like The Book of Vampires lie. 10. The vampire played by Kinski, consecrates a vivid figure. More than just a creeping silhouette or ghastly spectre or latent metaphor of the plague, he is an entity of suffering resembling ourselves, even playing on our sympathy. Herzog's antiheroic vampire represents a disturbing rejection and distrust of bourgeois conventions and scientific axioms and is the incarnation of pessimism. Prawer states: "The secret, in the main, lies in Kinski's voice those beautifully modulated, soft, world-weary tones emanating from his cadaverous head with its red-rimmed eyes and rodent fangs, like the elegant movements of his mandarin clawed hands, make him a figure of pity as well as terror." (1980:72) 11. Prawer is positive and idealistic when explaining this distant link of parallel and simultaneous events between both Jonathan and Nina, considering their mutual love as the force that knows no limits. His statement, as all the references to the marital relationship between these two, leaves aside Jonathan's abandonment of his wife and, obviously, Nina's final hypothetical sexual submission to the vampire's embrace: "[A] spiritual influence is suggested, a love which is so strong that it can deflect the beloved's enemies from their dire purpose across many miles of land and sea." (1980:229) However, this is partly true, partly fallacious. Love is in the texture of the film, no doubt, but Murnau's Nosferatu is mainly about the frustration and agony of a never-materialized love, that of the undead for Nina, of Harker for the vampire, of Nina for Harker. In fact, the sequence of images showing both Nosferatu's approach to the terrified Jonathan and the Occidental's waiting is conceived only in Nina's mind. It is Nina, who rises from her bed in a somnambulistic dream "led by her passionate and covetous desire to have his husband near and take care of him." Jonathan is absolutely disconnected and alienated from the present and the aura of love in that moment, succumbing to the thorny essence of his delirium, a penance that serves his aspiration right, we suppose.

12. The undead's overall portrait is exploited for the sake of increasing suspense and tension, in several meaningful details. First of all, his eyes, or rather his phantasmagoric expression, is unveiled in the ghost coach scene in the mysterious and menacing shot presenting his obsessive reading of the contract. Moreover, the vampire's claw-like hands are emphatically "dismembered" from the rest of physical elements in this scene, endowing them with their own spirit and purpose as handlers and tamers of the coming winds. Also, Nosferatu's sharp, rat-like teeth, presented at the very end are the ivory manifestation of the night molester reflecting the essence of primitive fears and repressed horrors. Indeed the lines in The Book of Vampires refer to Nosferatu as a name that "rings like the cry of a bird of prey". 
Dracula is such a hopeless representation of the undead that he lacks the polymorphism Stoker's antagonist exhibits, the showing off of different masks and faces. If in Coppola's deconstructive adaptation of Dracula, the vampire metamorphoses from an unsettling, senile "other" in the Castle to the romantic young gentleman in the streets of London, in Murnau's film, the vampire remains the same portrait of sunken eyes and fragile vita throughout the film, deeply foreign although familiarly and even sympathetically depressed.

Contrary to the tradition that the vampire has no soul and, consequently, projects no shadow or reflection, Nosferatu is a two-folded chimera, the umbra and the imago whose silhouette is his raging double for the sinister purposes of his revitalization.

13. From a birth in the shadows under the besieging silhouette of the patriarchal vampire, Harker quickly becomes old and decays in the Balkans' purgatory. His despair is a prelude of the senile submission of a wasted life. On the other hand, by feeding on the Occidental's bourgeois nomenclature, Nosferatu seems to recover part of that intrepid and dreaming spirit of youth and adolescence. Prawer acknowledges:

"There is, after all, all psychologists have frequently pointed out, a good deal of analogy between the fate of such monsters and the adolescent experience: an appearance felt to be awkward and ungainly, the sprouting of hair in unaccustomed places, conflicts with father/creators, experiments with "bodies" in secluded spots, advances towards others in which aggression takes the form of love and love that aggression." (Prawer, 1980:247)

14. The audience witnesses Nosferatu's rising from the grave - first seen from the top - at the darkest corner in the hellish ship cellar and anticipates the frightening awakening of Nosferatu as a nightmare returned, as the repressed, within the specific socio-cultural parameters of Bremen. We have transcended the individual subjective interpretation of the text and reached the intersubjective level. Following Fowler's acknowledgements:

"Individuals do of course respond subjectively, but the practice of literary criticism is to engage in discussion towards agreement on interpretation and judgement ( ... ) Thus critical response is not subjective but intersubjective, something worked out within a community, and going beyond the level of the individual subject's consciousness." (1986:174)

15. Murnau sets his story in 1838 , which was actually the year of an outbreak of the plague in that German city.

16. Waller points out: "Within Bremen there is darkness sufficient for the vampire, who will not need to seek out of a cellar or ancient crypt." (1986:180)

17. Her beloved's salvation is her own as she, with no remorse for the one who has abandoned her, states in a moment, probably having her imminent sacrifice in mind: "Jonathan! Thank God you are safe! Now I feel that I too have been saved."

\section{References}

\section{Literature}

Berman, Jeffrey. Narcissism and the Novel. New York: New York University Press, 1991.

Bettelheim, Bruno. Psicoanálisis de los cuentos de hadas. Barcelona: Critica. Derrida, J. 1976, Of Grammatology, trans. Gayatri Chakravorty Spivak. Baltimore and London: Johns Hopkins University Press, 1979.

Eco, Umberto. The Role of the Reader: Exploration in the Semiotics of Texts. Bloomington and London: Indiana University Press, 1979.

Eisner Lotte H. The Haunted Screen: Expressionism in the German Cinema and the Influence of Max Reinhardt, trans. Robert Graves. Berkeley: University of California Press, 1969, p.97.

Fish, Stanley. "Why no one's afraid of Wolfgang Iser", Diacritics 11, No. 1, 1981; pp. 2-13. 
Fowler, Roger. Linguistic Criticism. Oxford: Oxford University Press, 1986.

Gadamer Hans-Georg. Wahrheit and Methode. Tübingen: Mohr, 1972.

Glover, David. "Travels in Romania - Myths of Origin, Myths of Blood" in Dracula, ed. Glennis Byron. London: MacMillan Press, 1999.

Halberstam, Judith. "Technologies of Monstrosity: Bram Stoker's Dracula," in Dracula, ed. Glennis Byron. London: MacMillan Press, 1999.

Iser, Wolfgang. "Indeterminacy and the reader's response to prose fiction", in Miller, J. Hillis (ed.) Aspects of Narrative. New York: Columbia University Press, 1971.

The Implied Reader: Patterns of Communication in Prose Fiction from Bunyan to Beckett. Baltimore: Johns Hopkins University Press, 1974.

. The Act of Reading: A Theory of Aesthetic Response. Baltimore and London. Johns Hopkins University Press, 1978.

Jauss Hans R. Aesthetic Experience and Literary Hermeneutics trans. Michael Shaw Minneapolis: University of Minnesota Press, 1982.

Keppler C. F. The Literature of the Second Self, Tucson, 1972.

Kracauer, Siegfried. From Caligari to Hitler: A Psychological History of the German Film. Princeton: Princeton University Press, 1947, p. 86.

Lowe, Donald M. History of Bourgeois Perception. Chicago: University of Chicago Press, 1982.

Pope, Rebecca. "Writing and Biting in Dracula," in Dracula, Glennis Byron (ed.). Hampshire and London: MacMillan Press, 1999.

Prawer, S. S. Caligari's Children. Da Capo Press: New York, 1980.

Rimmon-Kenan. Narrative Fiction: Contemporary Poetics. London: Routledge, 1994.

Robert, Marthe. Novela de los origenes y origenes de la novela. Madrid: Taurus, 1973.

Shelley, Mary. Frankenstein [1818], Ed. M.K. Joseph. Oxford: OUP, 1980.

Shklovski, Victor. "Art as Technique," in Lee T. Lemon and Marion J. Reis, trans., Russian Formalist Criticism. Four Essays. Lincoln: University of Nebraska Press, 1965, pp. 11, 12.

Stoker, Bram. Dracula [1897]. Hindle, Maurice, Ed. London: Penguin, 1993.

Waller, Gregory A. The Living and the Undead From Stoker's Dracula to Romero's Dawn of the Dead. Urbana and Chicago: University of Illinois, 1986.

\section{Author Information}

Julio Ángel OLIVARES MERINO teaches Stylistics, Literary Texts, Gothic and Horror Films, at the University of Jaén (Spain). He is also a fiction writer, poet and musician. Among his publications are two novels, Condado de Brujas and Crepusculo Vitae, some novellas, as well as a series of gothic legends and non-fiction studies on vampires. 